\title{
Alveolar epithelial and endothelial cell apoptosis in emphysema: What we know and what we need to know
}

\author{
Mathieu C Morissette \\ Julie Parent \\ Julie Milot
}

Centre de Recherche de l'Hôpital Laval, Institut Universitaire de Cardiologie et de Pneumologie de I'Université Laval, Québec, Canada

Correspondence: Julie Milot 2725, chemin Ste-Foy, Québec (Qc), Canada, GIV 4G5

$\mathrm{Tel}+\mathrm{I} 4186564747$

Fax +I 4186564762

Email julie.milot@crhl.ulaval.ca

\begin{abstract}
Emphysema is mainly caused by cigarette smoking and is characterized by the loss of alveolar integrity and an enlargement of the alveolar space. However, mechanisms involved in its development are not fully understood. Alveolar cell apoptosis has been previously investigated in the lung of emphysematous subjects as a potential contributor to the loss of alveolar cell and has been found abnormally elevated. Though, mechanisms involved in the increased alveolar apoptosis that occurs in emphysema have now become a prolific field of research. Those mechanisms are reviewed here with special focus on how they affect cell viability and how they may be implicated in emphysema. Moreover, we suggest a model that integrates all those mechanisms to explain the increased alveolar apoptosis observed in emphysema. This review also includes some reflections and suggestions on the research to come.
\end{abstract}

Keywords: emphysema, apoptosis, proteases, VEGF, oxidative stress, TRAIL, autoimmunity

\section{Introduction}

According to the World Health Organization, chronic obstructive pulmonary disease (COPD) is believed to become the third cause of death by 2030 with cigarette smoking as the main cause. ${ }^{1}$ COPD features two main phenotypes: chronic bronchitis and emphysema with different physiopathology and symptoms. Emphysema has retained attention for its micro- and macroscopical manifestations: the loss of alveolar integrity and an enlargement of the alveolar space. ${ }^{2}$ This leads to a poor gas exchange at the alveolar level and to the retention of air caused by airways collapse due to the loss of elastic recoil (hyperinflation). ${ }^{2}$ But what is literally destructing the lung parenchyma of emphysematous patients? Proteases have been blamed very early, as deficiency in $\alpha 1$-antitrypsin (A1AT), the most important antiprotease of the lung, causes noxious gas-independent emphysema at an early age. ${ }^{3}$ Emphysema was first considered a neutrophilic disease, neutrophils being the major protease generator of all immune cells. ${ }^{4}$ However, as research progressed, emphysema was revealed to be a much more complex disease also involving alveolar macrophages (AM) ${ }^{5}$ and cytotoxic CD8+ T lymphocytes (CTL). ${ }^{6}$ Therefore, emphysema is now considered a complex inflammatory disease with only partly understood physiopathology. But the question remains: why and how alveolar structure is disappearing? Recently, new hypothesis rose trying to answer this question, among those was "apoptosis", a complex and well-regulated process that leads to cell death. In this review, we will focus on the recent developments made on the involvement of apoptosis in emphysema and on the possible molecular mechanisms involved in the initiation and progression of the disease. 


\section{What we know}

\section{Apoptosis}

Mechanisms involved in the programmed cell death are very complex but quite well described. There are many reasons why a cell would undergo apoptosis, among them: growth factor deprivation, mitotic aberrations, loss of contact with the extracellular matrix, direct induction by immune cells, activation of death receptors by soluble death ligands, and heavy damages caused by various stresses. All these "stimuli" will lead to cell apoptosis but will trigger different intracellular pathways to achieve their goal. The two main apoptotic pathways are the extrinsic and the intrinsic pathways, both leading to DNA fragmentation and cell death.

\section{The extrinsic pathway}

The extrinsic pathway (Figure 1) is triggered mostly by death ligands such as tumor necrosis factor (TNF), Fas ligand (FasL), and TNF-related apoptosis-inducing ligand (TRAIL) through their respective receptors. ${ }^{7}$ Briefly, the intracellular death domains of those receptors will, after autophosphorylation, recruit various adaptor molecules such as Fas-associated death domain (FADD). If all recruiting steps are encountered, procaspase-8/10 will be cleaved into their active form, caspase-8/10. Caspases (cystein-aspartase) are cystein proteases found in their pro-form (inactive form) in living cells. Following specific cleavage, they will acquire their protease activity and will start to cleave specific substrates and activate other caspases. Once cleaved, those substrates will transmit the apoptotic signal to the nucleus or mitochondria (caspase$3,6,7$ ) or interfere with the anti-apoptotic protection (cellular FLICE-like inhibitory protein [cFLIP]). In addition, cleavage of the BH3-interacting domain death agonist (Bid) to truncated Bib (tBid) will activate the intrinsic pathway.

\section{The intrinsic pathway}

The intrinsic pathway (Figure 1) is mainly triggered by cellular stresses that cause DNA damages like oxidative stress or UV light. ${ }^{8}$ Briefly, DNA damages will lead to the tumor suppressor $\mathrm{p} 53$ activation, stabilization, and to the acquisition of its transcription factor activity. Among its targets, p53 will either induce cell-cycle associated genes

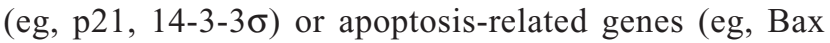

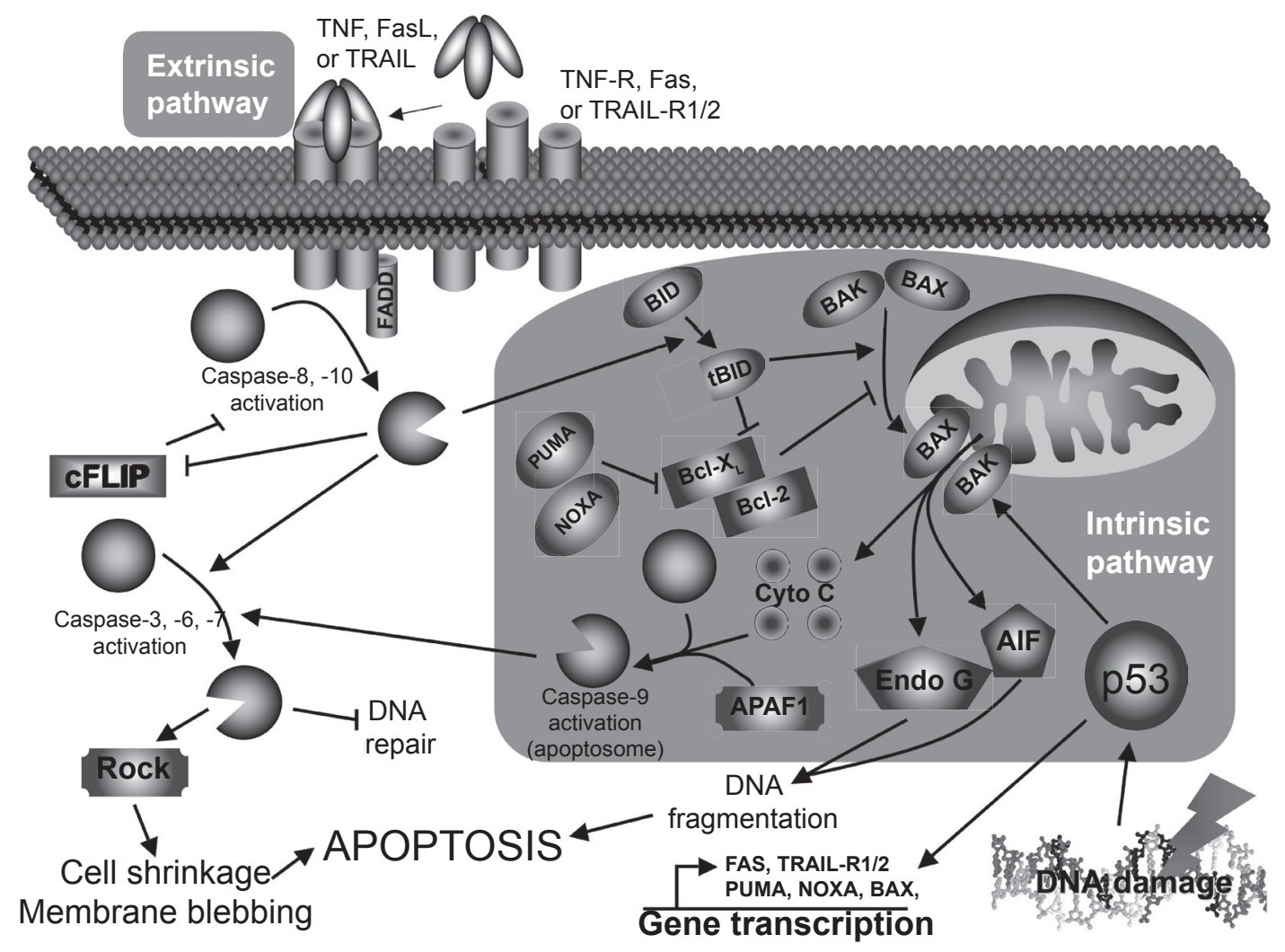

Figure I Apoptosis pathways.

Abbreviations: cFLIP, cellular FLICE-like inhibitory protein; FADD, Fas-associated death domain; FasL, Fas ligand; TNF, tumor necrosis factor; TRAIL,TNF-related apoptosis-inducing ligand; TRAIL-R,TRAIL receptor; Rock, Rho kinase; AIF, apoptosis-inducing factor; PUMA, p53 upregulated modulator of apoptosis; NOXA, damage. 
[Bcl-2-associated X protein], NOXA [Latin for damage], PUMA [p53 upregulated modulator of apoptosis], Fas, TRAIL-R1/2) transcription, depending on the DNA damage severity. If damages are too severe, p53 will lead to apoptosis: Bax, NOXA, and PUMA will massively translocate to the mitochondria outer-membrane and facilitate the formation of channels that will allow pro-apoptotic factors to move to cytoplasm (DNAse, cytochrome c, and anti-apoptotic factors inhibitors). Cytochrome $\mathrm{c}$ will join Apaf-1 and caspase-9 to form the so-called apoptosome (activated caspase-9) that will activate caspase-3. As mentioned earlier, the extrinsic pathway can also activate the intrinsic pathway through Bid cleavage (tBid) by caspase-8/10, and help cytosolic Bax to translocate to the mitochondria and induce the release of the mitochondriacontained apoptosis factors.

\section{Finalities}

No matter how apoptosis is induced or which pathway is involved, the finalities will be very similar. ${ }^{9}$ The most obvious observation is the dynamic membrane blebbing that precedes apoptotic bodies formation. Moreover, the membrane lipid phosphatidyl serine (PS) normally localized on the cytoplasmic side of the cell membrane will be externalized and used by scavenger cells to recognize apoptotic cells, leading to efficient cell clearance. DNA will also be affected, with features like chromatid condensation, its fragmentation into 180-200 bp fragments (endonuclease $\mathrm{G}$ [Endo $\mathrm{G}]$, apoptosis-inducing factor $[\mathrm{AIF}])$, and redistribution of the genetic material into the forming apoptotic bodies (Rho kinase [ROCK]). All those changes will lead to a clean cell death without intracellular material loss and to the phagocytosis of apoptotic bodies by immune or adjacent structural cells.

\section{Apoptosis and emphysema: cellular mechanisms}

Presence of higher apoptosis level in the human emphysematous lung has been reported numerous times in previous years (Table 1) and has been associated to decreased alveolar surface area, ${ }^{10}$ but also to increased alveolar cell proliferation, ${ }^{11}$ suggesting that regeneration processes of the emphysematous lung might be overwhelmed by its destruction or impared by unknown mechanisms. To explain this phenomenon, mechanisms involved in the regulation of cell survival and cell death have been studied in vivo (animal models, see Table 2), ex vivo, and in vitro. Here, we are summarizing the main mechanisms and their impacts on alveolar apoptosis that occurs in emphysema.

\section{Protease-induced apoptosis What are proteases?}

Proteases are proteins able to cleave specific amino-acid sequences and are implicated in many biological processes. In the lung, as in other tissues, proteases activity is closely controlled by anti-proteases. Though, protease/anti-protease balance is an extremely important factor for tissue homeostasis.

\section{What is known about proteases in apoptosis?}

In addition to their role in protein turnover, cell migration, and lung immunity, it has been shown that proteases can also induce lung epithelial and endothelial cell apoptosis (Figure 2). ${ }^{12-14}$ In fact, Suzuki and colleagues ${ }^{14}$ showed that leukocyte elastase (LE), mainly released by activated polymorphonuclear leucocytes, can induce small airway and alveolar epithelial cell apoptosis through the intrinsic pathway and by decreasing AKT phosphorylation (antiapoptotic factor) following proteinase-activated receptor 1 (PAR-1) activation. Yang and colleagues ${ }^{12}$ also demonstrated a similar effect of neutrophil elastase (NE) and proteinase 3 (PR3), mainly secreted by activated neutrophils, on primary bovine arterial endothelial cells. On the other side, it has been demonstrated that the protease inhibitor $\alpha 1$-antitrypsin (A1AT) may act as a survival factor by preventing lung endothelial cell death induced by staurosporine ${ }^{15}$ and cigarette smoke $^{16}$ through active caspase inhibition. Moreover, increasing evidences suggest that "tissues inhibitor of metalloproteinases-1" (TIMP-1) may act as a survival factor through CD63-mediated extracellular signal-regulated kinase (ERK) and AKT activation. ${ }^{17}$ Taken together, these data suggest that protease/anti-protease imbalance can promote apoptosis both through direct activation of PAR-1 signaling and through the reduction of antiproteases' ability to inhibit apoptotic processes.

\section{What is known about proteases in promoting apoptosis in emphysema?}

Discovering that A1AT deficiency, the main inhibitor of NE, confers susceptibility to emphysema development ${ }^{18}$ and that emphysema-like changes can be induced by elastolytic enzymes instillation in animal models (elastase emphysema $)^{19}$ were at the fundaments of the protease hypothesis of emphysema development. In fact, proteases such as $\mathrm{NE},{ }^{20}$ cathepsins L, ${ }^{21}$ and matrix metalloproteinases (MMP)-1, ${ }^{22,23}$ $-2,22,24-8,{ }^{22}-9,,^{22,24}$ and $-12^{25}$ are increased in the emphysematous lung mainly due to a higher number of activated neutrophils and macrophages. The lung protease hyperactivity 
Table I Characteristics of studies reporting elevated apoptosis in the emphysematous lung

\begin{tabular}{|c|c|c|c|c|}
\hline Authors & Studied group & Control group & $\begin{array}{l}\text { Apoptosis detection } \\
\text { technique }\end{array}$ & Apoptotic cell type \\
\hline Segura-Valdez et al $2000^{22}$ & Smokers with emphysema & $\begin{array}{l}\text { Smokers and nonsmokers } \\
\text { without COPD }\end{array}$ & In situ end labeling & Mainly endothelial cells \\
\hline Kasahara et al $2000^{40}$ & Smokers with emphysema & $\begin{array}{l}\text { Smokers and nonsmokers } \\
\text { without emphysema }\end{array}$ & $\begin{array}{l}\text { DNA fragmentation (TUNEL } \\
\text { and LM-PCR) Single DNA } \\
\text { detection (IHC) }\end{array}$ & $\begin{array}{l}\text { Epithelial and } \\
\text { endothelial cells }\end{array}$ \\
\hline Yokohori et al $2004^{\prime \prime}$ & $\begin{array}{l}\text { Subjects with emphysema } \\
\text { (smoking state not specified) }\end{array}$ & $\begin{array}{l}\text { Smokers and nonsmokers } \\
\text { without emphysema }\end{array}$ & DNA fragmentation (TUNEL) & $\begin{array}{l}\text { Epithelial cells (mainly } \\
\text { type II alveolar cells) }\end{array}$ \\
\hline Calabrese et al $2005^{97}$ & $\begin{array}{l}\text { Subjects with AAT-deficiency } \\
\text { emphysema }\end{array}$ & $\begin{array}{l}\text { Young subjects with } \\
\text { unspecified smoking history }\end{array}$ & $\begin{array}{l}\text { DNA fragmentation (TUNEL } \\
\text { and agarose gel separation) }\end{array}$ & Alveolar wall cells \\
\hline Imai et al $2005^{10}$ & $\begin{array}{l}\text { Ex-smokers (>6 months) } \\
\text { with emphysema }\end{array}$ & $\begin{array}{l}\text { Nonsmokers with } \\
\text { unspecified lung functions }\end{array}$ & $\begin{array}{l}\text { cleaved caspase-3 and PARP } \\
\text { (Western blot) and DNA } \\
\text { fragmentation (agarose gel } \\
\text { separation) }\end{array}$ & Not mentionned \\
\hline
\end{tabular}

Abbreviations: COPD, chronic obstructive pulmonary disease; IHC, immunohistochemistry; LM-PCR, ligation-mediated polymerase chain reaction; PARP, poly(ADP-ribose) polymerase; TUNEL, terminal deoxynucleotidyl transferase biotin-dUTP nick end labeling.

is believed to affect alveolar integrity by degrading elastic fibres responsible for the maintenance of alveolar structure and lung stretch. However, it seems that elastase-induced emphysema may not be attributable only to elastic fibre degradation. In fact, elastase activity is detectable for only 45 to 50 minutes after elastase instillation while emphysema phenotype and higher alveolar apoptosis remain for weeks, ${ }^{26}$ probably due to the installation of an inflammatory state.
Supporting that hypothesis, mice knockout for IL-1 $\beta$ and TNF receptors gene and submitted to elastase instillation showed fewer emphysematous lesions as well as alveolar cells undergoing apoptosis, ${ }^{27}$ suggesting that elastase may promote disease progression and alveolar apoptosis through IL-1 $\beta$ and TNF-dependent mechanism. Moreover, in a mouse model of emphysema induced by local lung overexpression of interferon- $\gamma$, cathepsin $\mathrm{S}$ blockade, a protease involved

Table 2 Animal models used to study apoptosis in emphysema

\begin{tabular}{|c|c|c|c|}
\hline Authors & Model of emphysema & Apoptosis detection technique & Apoptotic cell type \\
\hline Kasahara et al $2000^{40}$ & $\begin{array}{l}\text { Subcutaneaous injection of a VEGF } \\
\text { receptor blocker (Sprague-Dawley rats) }\end{array}$ & $\begin{array}{l}\text { DNA fragmentation (TUNEL and } \\
\text { LM-PCR) Active caspase-3 (IHC) }\end{array}$ & $\begin{array}{l}\text { Alveolar epithelial } \\
\text { and endothelial cells }\end{array}$ \\
\hline Lucey et al $2002^{27}$ & $\begin{array}{l}\text { Intratracheal instillation of porcine } \\
\text { pancreatic elastase (B6/29SF2/J mice) }\end{array}$ & DNA fragmentation (TUNEL) & Alveolar epithelial cells \\
\hline Aoshiba et al $2003^{98}$ & $\begin{array}{l}\text { Single intratracheal delivery } \\
\text { of caspase- } 3 \text { (C57BL/6 mice) }\end{array}$ & $\begin{array}{l}\text { DNA fragmentation (TUNEL) } \\
\text { and ssDNA detection (IHC) }\end{array}$ & Mainly alveolar epithelial cells \\
\hline Bartalesi et al $2005^{99}$ & $\begin{array}{l}\text { Whole-body exposure to cigarette } \\
\text { smoke (C57BL/6 and DBA/2 mice) }\end{array}$ & DNA fragmentation (TUNEL) & $\begin{array}{l}\text { General increase but } \\
\text { unspecified cell type }\end{array}$ \\
\hline Kuo et al $2005^{100}$ & $\begin{array}{l}\text { Whole-body exposure to cigarette } \\
\text { smoke (Wistar rats) }\end{array}$ & DNA fragmentation (TUNEL) & $\begin{array}{l}\text { General increase but } \\
\text { unspecified cell type }\end{array}$ \\
\hline Zheng et al $2005^{28}$ & $\begin{array}{l}\text { Transgenic lung IFN- } \gamma \text { overexpression } \\
\text { (CCI0-rtTA-IFN- } \gamma \text { mice })\end{array}$ & DNA fragmentation (TUNEL) & $\begin{array}{l}\text { Mainly alveolar Type I } \\
\text { and Type II cells }\end{array}$ \\
\hline Petrache et al $2005^{101}$ & $\begin{array}{l}\text { Single intratracheal delivery of } \\
\mathrm{C}_{12} \text { ceramide (C57BL/6 mice) }\end{array}$ & DNA fragmentation (TUNEL) & $\begin{array}{l}\text { Mainly endothelial cells but also } \\
\text { Type II alveolar epithelial cells }\end{array}$ \\
\hline $\begin{array}{l}\text { Taraseviciene-Stewart } \\
\text { et al } 2005^{85}\end{array}$ & $\begin{array}{l}\text { Anti-endothelial cells immunization } \\
\text { that triggered autoimmune response } \\
\text { (Sprague-Dawley rats) }\end{array}$ & $\begin{array}{l}\text { DNA fragmentation (TUNEL) } \\
\text { and active caspase- } 3 \text { (IHC) }\end{array}$ & Alveolar epithelial cells \\
\hline Brass et al $2008^{102}$ & $\begin{array}{l}\text { Exposure to lipopolysaccharide } \\
\text { (C57BL/6 mice) }\end{array}$ & $\begin{array}{l}\text { DNA fragmentation (TUNEL) and } \\
\text { active caspase- } 3 \text { (Western blot) }\end{array}$ & Alveolar epithelial cells \\
\hline
\end{tabular}

Abbreviations: IFN, interferon; IHC, immunohistochemistry; LM-PCR, ligation-mediated polymerase chain reaction;TUNEL, terminal deoxynucleotidyl transferase biotin-dUTP nick end labeling;VEGF, vascular endothelial growth factor. 


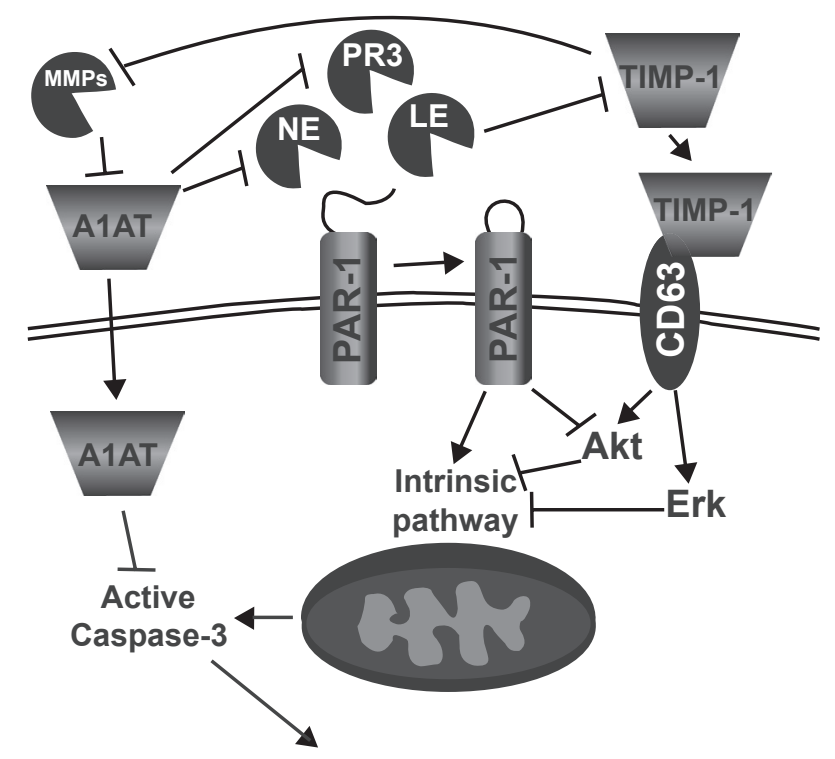

APOPTOSIS

Figure 2 Mechanisms by which leucocyte elastase (LE), neutrophil elastase (NE), and proteinase 3 (PR3) may induce alveolar epithelial and endothelial cell apoptosis. $\alpha-1$ antitrypsin (AIAT), proteinase activated receptor I (PAR-I), matrix metalloproteinase (MMP), tissue inhibitor of matrix metalloproteinase (TIMP), extracellular-signal regulated kinase (ERK).

in the antigen presentation process, limited the increase of apoptosis, ${ }^{28}$ linking proteases once more with apoptosis in emphysema.

\section{Decreased VEGF signaling What is VEGF?}

Vascular endothelial growth factor (VEGF) is a powerful angiogenic molecule with two receptors (VEGFR1 and 2) triggering opposite cell responses. VEGFR1 is mainly responsible for the inhibition of endothelial cell migration and proliferation, when VEGFR2 tends to promote those processes. VEGF is found in great amount in the lung and act as a key factor in the endothelial maintenance..$^{29}$

\section{What is known about VEGF in apoptosis?}

In regard to apoptosis and cell survival, it is known that VEGF, by itself, can inhibit serum deprivation-induced endothelial cell apoptosis in vitro. ${ }^{30,31}$ VEGF increases cell survival through phosphoinositide-3 kinase (PI3K)/Akt pathway activation ${ }^{32}$ leading to caspase- 9 and Bad inactivation $^{33,34}$ and also by increasing the expression of the anti-apoptotic molecules Bcl-2, A1, ${ }^{30}$ survivin, and XIAP. ${ }^{35}$ VEGF is also able to prevent ceramide-induced HMEC (human microvascular endothelial cells) apoptosis through MAPK/ERK pathway activation and SAPK/JNK pathway inhibition. ${ }^{31}$
What is known about decreased VEGF signaling in promoting apoptosis in emphysema?

The role of VEGF signaling in the emphysema pathophysiology has raised significant interest in the past years. ${ }^{36,37}$ It has been shown that VEGF and VEGFR2 levels were decreased in the lung of emphysematous subjects compared to healthy controls $^{38}$ and were related to increased alveolar cell apoptosis. ${ }^{39}$ Cigarette smoke-exposed Sprague-Dawley rats also show decreased lung VEGF and VEGFR2. ${ }^{38}$ Moreover, rats treated with the VEGF receptor blocker SU5416 developed emphysema-like phenotype, condition that may be prevented by the administration of the caspase inhibitor Z-Asp- $\mathrm{CH}_{2}-$ $\mathrm{DCB},{ }^{40}$ suggesting that decreased VEGF signaling may induce apoptotic process leading to emphysema. In addition, SU5416 treated rats presented evidences of alveolar oxidative stress (higher 8-hydroxyguanine and 4-hydroxynonenal staining). ${ }^{41}$ In this model, oxidative stress and emphysema may be prevented by the administration of the superoxyde dismutase mimic M40419, ${ }^{41}$ by $\mathrm{N}$-acetylcystein (NAC), ${ }^{42}$ and, interestingly, by the caspase inhibitor Z-Asp- $\mathrm{CH}_{2}-$ $\mathrm{DCB},{ }^{41}$ revealing that the apparition of oxidative stress is caspase-dependent. Taken together, these data suggest that decreased VEGF signaling may be responsible for endothelial cell apoptosis. However, the capillary bed appears essential for the growth and maintenance of alveolar septa. ${ }^{43}$ Moreover, as demonstrated in human fetal lung ${ }^{44,45}$ and in adult lung, ${ }^{46}$ VEGF is released principally by respiratory epithelial cells. Therefore, it may lead to a potential vicious circle that will cause endothelial and epithelial cell apoptosis (Figure 3).

\section{Oxidative stress}

\section{What is oxidative stress?}

Basically, oxidative stress happens when a cell is exposed to molecules with important oxidative power such as free radicals. If the oxidative defenses are strong enough, cellular damages will be negligible. However, if the oxidative aggression is too strong or if it persists for too long, cellular damages may then be very important.

\section{What is known about oxidative stress in apoptosis?}

It is well known that oxidative stress can trigger numerous cell responses, including the signaling cascade that will lead to apoptosis (through the intrinsic pathway), and many studies are available on the subject. ${ }^{47}$ In vitro, exogenous hydrogen peroxide $\left(\mathrm{H}_{2} \mathrm{O}_{2}\right)$ or compounds that promote endogenous production of reactive oxygen species (ROS) (eg, arsenic trioxide, ${ }^{48}$ anthracyclines, ${ }^{49}$ bleomycin, ${ }^{50} \mathrm{~N}$-(4-hydroxyphenyl) retinamide ${ }^{51}$ ) are usually used to create oxidative stress. 


\section{Cigarette smoke \\ (Oxidative stress)}

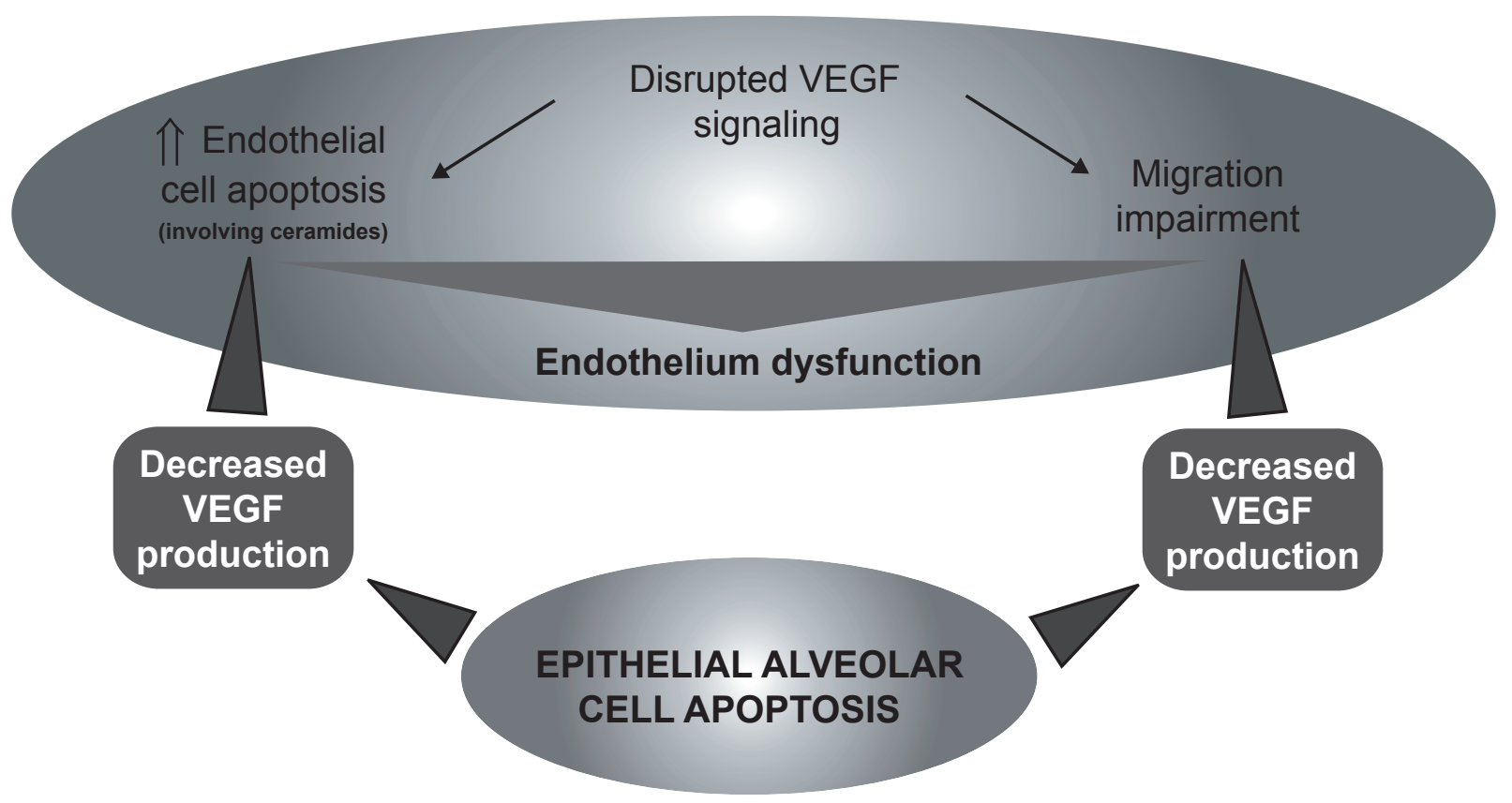

Figure 3 Cigarette smoke (oxidative stress)-mediatedVEGF signaling disruption leading to endothelial cell death, migration impairment, and general endothelium dysfunction causing epithelial cells apoptosis.

Abbreviation: VEGF, vascular endothelial growth factor.

In the majority of cell types, those treatments will trigger apoptosis through the intrinsic pathway as previously discussed (Figure 1). ${ }^{47}$ Another feature of oxidative stressinduced apoptosis is the activation of the mitogen-activated protein kinase (MAPK) pathways ERK 1/2, jun N-terminal kinase (JNK), and p38 MAPK). The JNK pathway seems to be pro-apoptotic as its inhibition promotes survival in primary rat alveolar epithelial cells treated with $\mathrm{H}_{2} \mathrm{O}_{2} .{ }^{52} \mathrm{On}$ the other side, ERK 1/2 and p38 MAPK tend to have important antiapoptotic effects as their inhibition impairs cell survival. ${ }^{52}$ However, activation and cellular effects of MAPK pathways are known to be different according to cell types studied.

Main defenses against oxidative stress are antioxidant molecules and enzymes. The major antioxidants found in the lung are superoxide dismutase (superoxide anion scavenger), catalase (converts $\mathrm{H}_{2} \mathrm{O}_{2}$ to water), and glutathione peroxidase (converts organic hydroperoxides to organic hydroxides). ${ }^{53}$

\section{What is known about oxidative stress in promoting} apoptosis in emphysema?

In the case of emphysema, oxidant molecules have two main origins. The first is of course cigarette smoke (active smoker), which contains free radicals with tremendous oxidative power such as superoxide $\left(\mathrm{O} 2 \bullet^{-}\right)$, hydroxyl radical $(\bullet \mathrm{OH})$, and hydrogen peroxide $\left(\mathrm{H}_{2} \mathrm{O}_{2}\right) \cdot{ }^{54}$ It is important to note that nonemphysematous smokers are also exposed to the oxidative agents contained in cigarette smoke, suggesting that smokers who have developed emphysema (15\%-20\%) reacted differently or were more susceptible to this stress. The second source, and probably the most sustained, comes from the chronic inflammation inherent to emphysema that persists even after smoking cessation. ${ }^{55}$ Activated macrophages and neutrophils, present in higher number in the emphysematous lung, ${ }^{56-59}$ are powerful producers of reactive oxygen species (ROS) ${ }^{60,61}$ It is well known that the lung antioxidant defenses of subjects with emphysema are overwhelmed, leading to important oxidative damages. In fact, compared to those of normal smokers and ex-smokers, the emphysematous lung presents more damaged proteinsand more peroxidated lipids. ${ }^{62,63}$ All those oxidative damages may then lead to the increased alveolar apoptosis observed in emphysema (Figure 4).

\section{TRAIL-mediated apoptosis What is TRAIL?}

Tumor necrosis factor-related apoptosis-inducing ligand (TRAIL) is a member of the death ligand TNF family that also includes FasL. TRAIL has four receptors: TRAIL-R1 


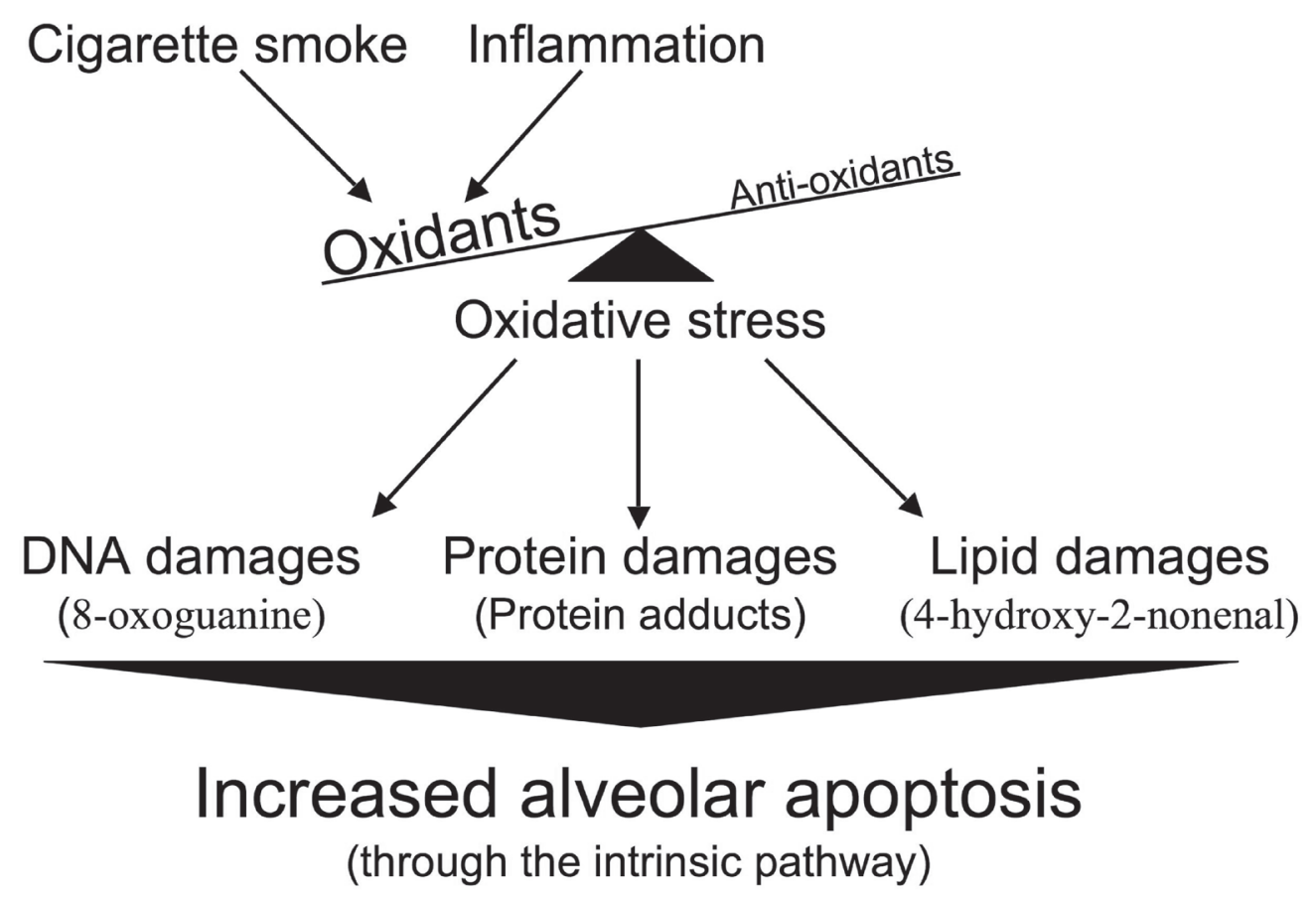

Figure 4 Increased alveolar apoptosis mediated through oxidative stress-induced cellular damages.

and R2 which contain functional death domains, TRAIL-R3 which contains a truncated death domain and acts as a decoy, and TRAIL-R4 which is unable to induce apoptotic signals but, as well as TRAIL-R1 and R2, can activate kinases that will lead to NF- $\kappa$ B activation. ${ }^{64}$

\section{What is known about TRAIL in apoptosis?}

First interest on TRAIL has been brought by its ability to induce transformed/cancer cell apoptosis while having no such effects on normal cells. ${ }^{65}$ Further research has shown that not all transformed/cancer cells were sensitive to its apoptotic signal. ${ }^{66}$ Interestingly, DNA damage and ROS generating agents are able to suppress cellular resistance to TRAIL-mediated apoptosis in many cell lines, including the lung adenocarcinoma cell line A549. ${ }^{67-69}$ Moreover, in a mouse model of Alzheimer's disease, a disease characterized by a progressive lost of neuronal cells, blockade of TRAILR2 prevents $\beta$-amyloid-induced neuronal cell apoptosis. ${ }^{70}$ The main cells releasing TRAIL are activated macrophages, NK cells, and T lymphocytes. ${ }^{71-73}$

What is known about TRAIL in promoting apoptosis in emphysema?

TRAIL receptors 1, 2, and 3 have been shown to be upregulated in the alveolar epithelial cells of emphysematous smokers and ex-smokers. ${ }^{74}$ Moreover, their expression was closely related to the levels of the tumor suppressor p53 in the emphysematous lung parenchyma. ${ }^{74}$ Interestingly, A549 cells (lung adenocarcinoma cell line) exposed in vitro to oxidative stress $\left(\mathrm{H}_{2} \mathrm{O}_{2}\right)$ and TNF had higher expression of TRAIL-R1, 2 , and 3 but also higher levels of $\mathrm{p} 53,{ }^{74}$ suggesting that the modulation of the TRAIL system observed in the emphysematous lung may be attributable to oxidative stress and/or inflammatory cytokines. As TRAIL is released by activated inflammatory cells, oxidative stress and inflammation present in the emphysematous lung may sensitize alveolar cells to its apoptotic effects (Figure 5).

\section{Killer cells and autoimmunity What are killer cells and autoimmunity?}

Killer cells are immune cells specialized in the act of killing infected or unwanted cells. There are mainly two types of killer cells: cytotoxic CD8+ T lymphocytes (CTL), members of the adaptive immunity, and natural killer (NK) cells, members of the innate immunity. The main difference between these two cell types is the way they recognize cells that have to be killed. When a given cell is infected with intracellular pathogens, major histocompatibility complex (MHC) class I will present pathogen peptides at the cell surface allowing CTL to recognize it with their T cell receptor (TCR) and kill the infected cell. ${ }^{75}$ On its side, with no TCR, NK cell cannot use by itself antigen-based recognition to identify cells to be killed. However, specific antigen-mediated cytotoxicity can be indirectly induced through antibody-dependent cellular 


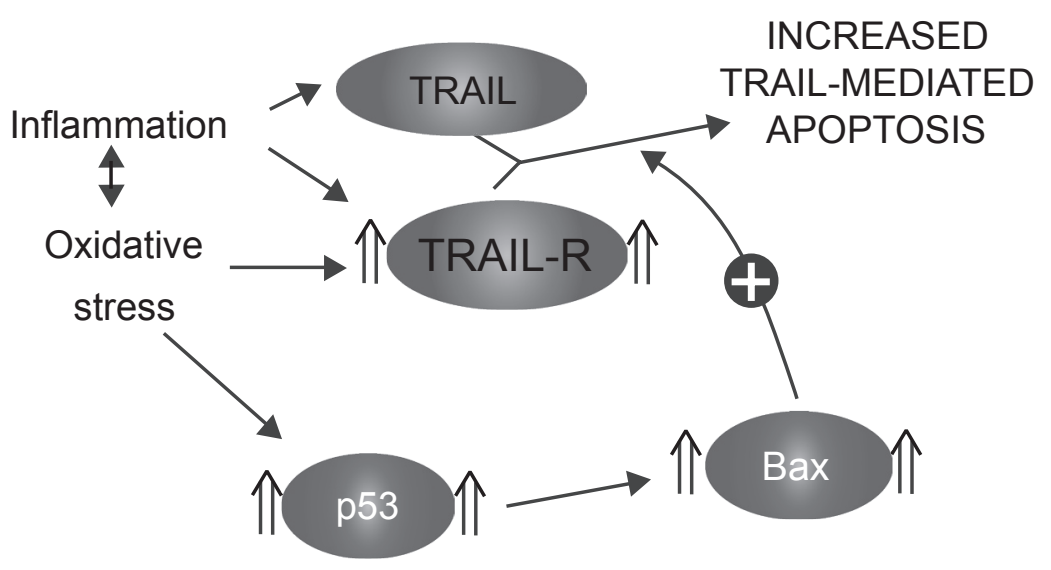

Figure 5 Sensitization to TRAlL-mediated apoptosis.

Abbreviation: TRAIL, tumor necrosis factor-related apoptosis-inducing ligand;TRAIL-R, TRAIL receptors.

cytotoxicity (ADCC) via the binding of FcyRIII (CD16) to the $\mathrm{Fc}$ portion of IgG bound to specific target cell membrane antigen. ${ }^{76}$

Autoimmunity is an inappropriate immune response against antigens of the host (self-antigen) and can be triggered by a variety of mechanisms; ${ }^{77}$ we describe here only those that may be relevant in emphysema. Autoimmune response can be triggered by modified self-antigen, as exposure of cells to agents that may affect protein integrity (eg, oxidants, proteases) can create molecules unknown to the immune system and cause autoimmune response. Moreover, molecules normally hidden from the immune system (located into the nucleus or the cytoplasm) may trigger autoimmune response if released. Failed clearance of apoptotic cells or high levels of necrosis may expose molecules normally sequestered to the cytoplasm or to the nucleus, as it is observed in systemic lupus erythematosus. ${ }^{78}$

\section{What is known about killer cells and autoimmunity in apoptosis?}

When an immune response is initiated against a self-antigen, processes involved in the targeting and recognition by antibodies or killer cells are very similar to those raised against pathogens. First, the humoral response is involved: subjects with autoimmune diseases like systemic lupus erythematosus and rheumatoid arthritis are presenting autoantibodies in their serum. ${ }^{79}$ Those antibodies secreted by activated B cells will, after recognition of their specific antigens, trigger local inflammatory response to eliminate the cells that bears autoantigen/antoantibody complexes. ${ }^{80}$ As mentioned earlier, NK cell can recognize these cells and induce their apoptosis. In fact, following recognition, NK cell will induce target cell's apoptosis mainly trough the release of granules that contain cytotoxic molecules like "pore forming protein" (perforin), granzymes, and granulisin. Death ligands such as FasL and TRAIL also play an important role in the NK-mediated cell apoptosis. ${ }^{81}$ In addition to the antibodymediated immune response, a specific cellular response can be mediated by CD4+ and CD8+ T lymphocytes. Once CD4+ $\mathrm{T}$ lymphocytes have encountered their antigen presented by an antigen-presenting cell (APC) like dendritic cells, they will proliferate (oligoclonal expansion) and be involved in the activation of B cells and alveolar macrophages through cell/cell contact or the release of inflammatory mediators. ${ }^{82}$ On their side, activated CD8+ T lymphocytes will directly target cells that express the specific autoantigen and, with mechanisms similar to those used by NK cell, induce target cell apoptosis. ${ }^{83}$ All these processes will lead to the deletion of a specific autoantigen-bearing cell population.

What is known about killer cells and autoimmunity in promoting apoptosis in emphysema?

There are evidences that emphysema may have an autoimmune component. Autoreactive antibodies with avidity for pulmonary epithelial cells were found in the serum of about $70 \%$ of subjects with emphysema when only $10 \%$ of normal smokers or nonsmokers were positive ${ }^{84}$ Moreover, in vitro peripheral blood mononuclear cells cytotoxicity against pulmonary epithelial cells was stronger in presence of plasma from emphysematous subjects than from normal subjects, ${ }^{84}$ suggesting that autoreactive antibodies may initiate immune cell-mediated apoptosis. Moreover, a model of autoimmune emphysema (Table 2) revealed that immune response against lung endothelial cells can lead to alveolar endothelial and epithelial cell apoptosis and cause emphysema.$^{85}$ Antibodies against elastin protein have also been found in the serum 
of emphysematous subject ${ }^{86}$ as well as a higher number of B cells secreting anti-elastin antibodies in the emphysematous lung. ${ }^{86}$ In the same study, they also found that peripheral blood CD4+ T lymphocytes from emphysematous subjects were releasing more gamma interferon (IFN- $\gamma$ ) and interleukin-10 (IL-10) than those from normal subjects upon in vitro elastin exposure. ${ }^{86}$ Oligoclonal CD4+ T lymphocytes able to proliferate in vitro upon interleukin-2 stimulation ${ }^{87,88}$ as well as oligoclonal CD8+ $\mathrm{T}$ lymphocytes ${ }^{89}$ were found in the lung of subjects with emphysema. Moreover, CD8+ $\mathrm{T}$ lymphocytes from the lung of COPD subjects expressed higher levels of perforin and cytotoxic activity than those from controls, ${ }^{90.91}$ phenomenon that is not observed in the peripheral blood. ${ }^{92}$ All these data suggest the existence of a local antigen-driven cellular immunity in the lung of emphysematous subjects (Figure 6).

\section{What we need to know Which cell type is dying?}

There are three major structural cell types in the alveolar tissue: Type I alveolar cells, Type II alveolar cells, and endothelial cells. Type I alveolar is the most abundant cell type found in the alveolar tissue. They are responsible for the maintenance of the alveolar structure and gas diffusion toward alveolar capillaries. Type II alveolar cells are the major source of surfactant proteins and are the progenitor of Type I alveolar cells. Endothelial cells are in charge of lung perfusion and, with Type I alveolar cells, of gas diffusion between alveoli and blood. As all these cell types are important to maintain alveolar tissue integrity, the accelerated loss of one or another will have direct effect on the whole alveolar tissue. The technique of choice to detect apoptotic cells in the emphysematous lung is terminal deoxynucleotidyl transferase biotin-dUTP nick end labeling (TUNEL) analysis. Unlike tissue lysat-based analyses that only give a general view of the tissue apoptosis level (eg, Ligation-mediated polymerase chain reaction [LM-PCR], caspase-3 activity, poly(ADPribose) polymerase [PARP]) cleavage), TUNEL allows a precise identification of the cells that undergo apoptosis. However, despite comparative TUNEL analyses of normal and emphysematous lung (Table 1), no real consensus has been established on which cell type seems to die predominantly from apoptosis in the emphysematous lung.

According to the different hypothesis that attempt to explain the increased alveolar apoptosis that occurs in emphysema, different cell types are targeted as the earliest cell type touched by apoptosis. The VEGF hypothesis points mainly at endothelial cells ${ }^{40}$ when the proteases imbalance, ${ }^{14,27}$ oxidative stress, ${ }^{62}$ and TRAIL hypothesis ${ }^{74}$ tend to point at epithelial cells. Autoimmunity ${ }^{84,85}$ seems to be touching both endothelial and epithelial cells. If we consider the conformation of the alveoli, epithelial alveolar cells are exposed directly to cigarette smoke and may be acting as a "cellular shield" for endothelial cells. It is then logic to assume that

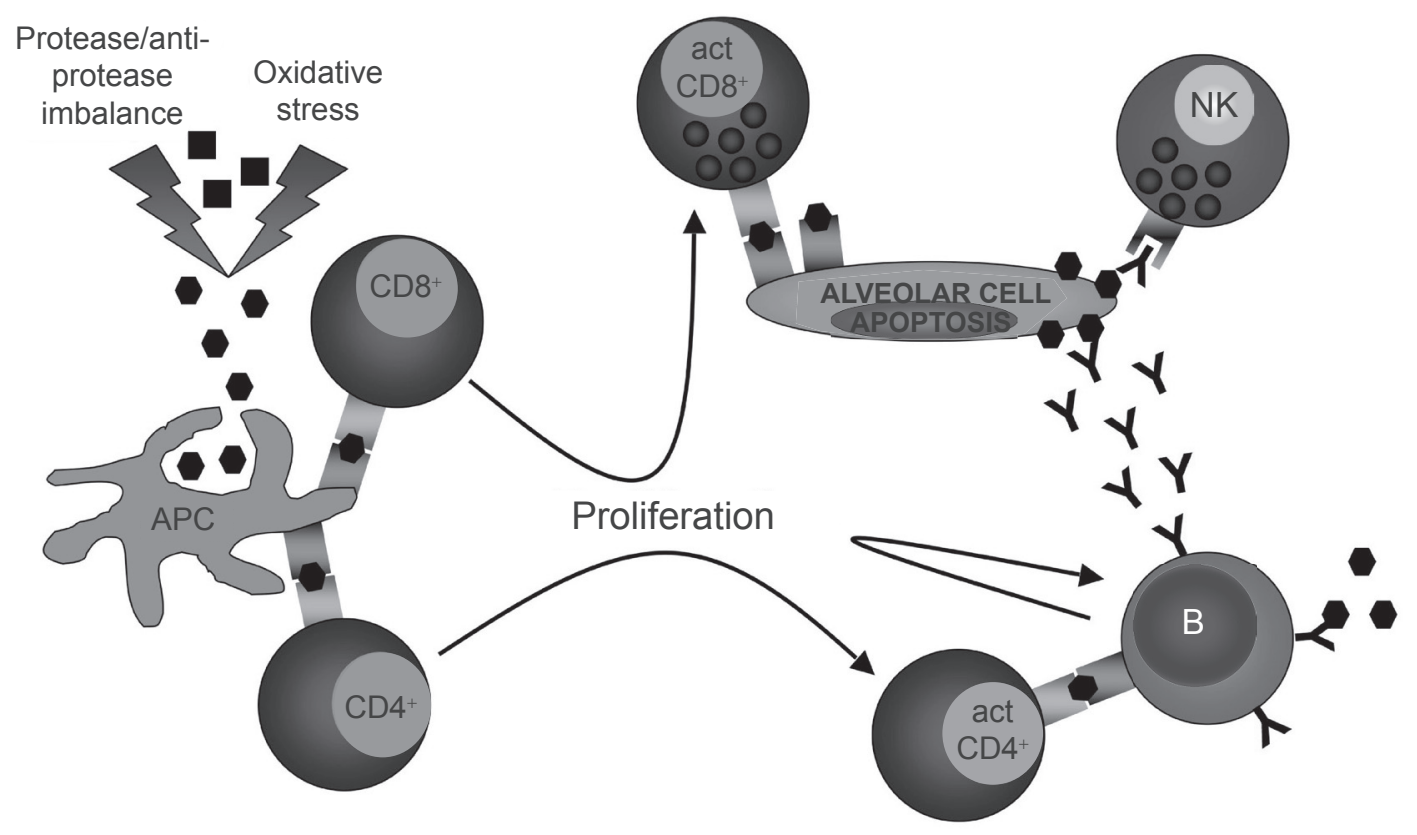

Figure 6 Induction of an autoimmune response against immunogenic self-antigens after protease and oxidative stress-induced modifications. Antigen-presenting cell (APC). Self-antigen $(\square)$, modified self-antigen $(\bullet)$, antibody against modified self-antigen $(\mathbf{Y})$. 
most of the damages induced by cigarette smoke will be first done to epithelial rather than endothelial cells. There is a lot of in vitro data on the effects of cigarette smoke on signaling pathways of alveolar epithelial and endothelial cells. However, no data are currently available on the crosstalk of alveolar epithelial cells exposed to cigarette smoke with endothelial cells. This would be extremely relevant to understand how damaged alveolar epithelial cells may affect the functions and the faith of endothelial cells, and would give important information on which cell type may be susceptible to undergo apoptosis first.

\section{When does it die?}

Until now, publications on apoptosis in emphysema compared the apoptosis levels in the lung of emphysematous subjects with well-developed disease with those of nonemphysematous subjects. From this, we can say that apoptosis levels are higher in emphysematous subjects despite smoking cessation and we can suppose that apoptosis is involved in the progression of the disease. We also know that alveolar epithelial cells' proliferation is increased, but does not seem to compensate for cell loss (apoptosis/proliferation imbalance). However, we do not know if the apoptotic mechanisms that have been described in this review are involved in the initiation of the disease or only in the progression once the disease has started. When does apoptosis overcome proliferation? When do proteases overcome anti-proteases?
When do VEGF and VEGFR2 levels go down? When do $\mathrm{p} 53, \mathrm{Bax} / \mathrm{Bcl}-\mathrm{x}_{\mathrm{L}}$ ratio, and TRAIL-R go up? And finally, when does autoimmunity get in play? Answering these questions is not an easy task. In order to do so, we would need to study for a long period of time smoking subjects that are susceptible to develop emphysema but that have not developed it yet. However, since there is no reliable method to identify these subjects yet, animal models and in vitro cell culture are the only tools that can help to understand mechanisms involved in emphysema initiation rather than on its progression.

\section{What is responsible for cell death?}

Looking for only one mechanism to explain the increased alveolar apoptosis would be an important mistake. Proteases, oxidative stress, decreased VEGF, autoimmunity, and TRAIL-mediated apoptosis are probably all involved at different levels in the increased apoptosis levels in emphysema. The elaboration of a complete model that would integrate all mechanisms and link them to each other may be extremely relevant to guide research on the increased apoptotic events observed in emphysema. Here, we propose a model (Figure 7) built from the studies we previously discussed. Emerging concepts or hypothesis such as alveolar apoptosis induced by neutrophils-derived defensins, ${ }^{93,94}$ link between innate immunity and oxidative stress through Toll-like receptor 4 (TLR4) tone, ${ }^{95}$ and reduced or impared apoptotic cell clearance

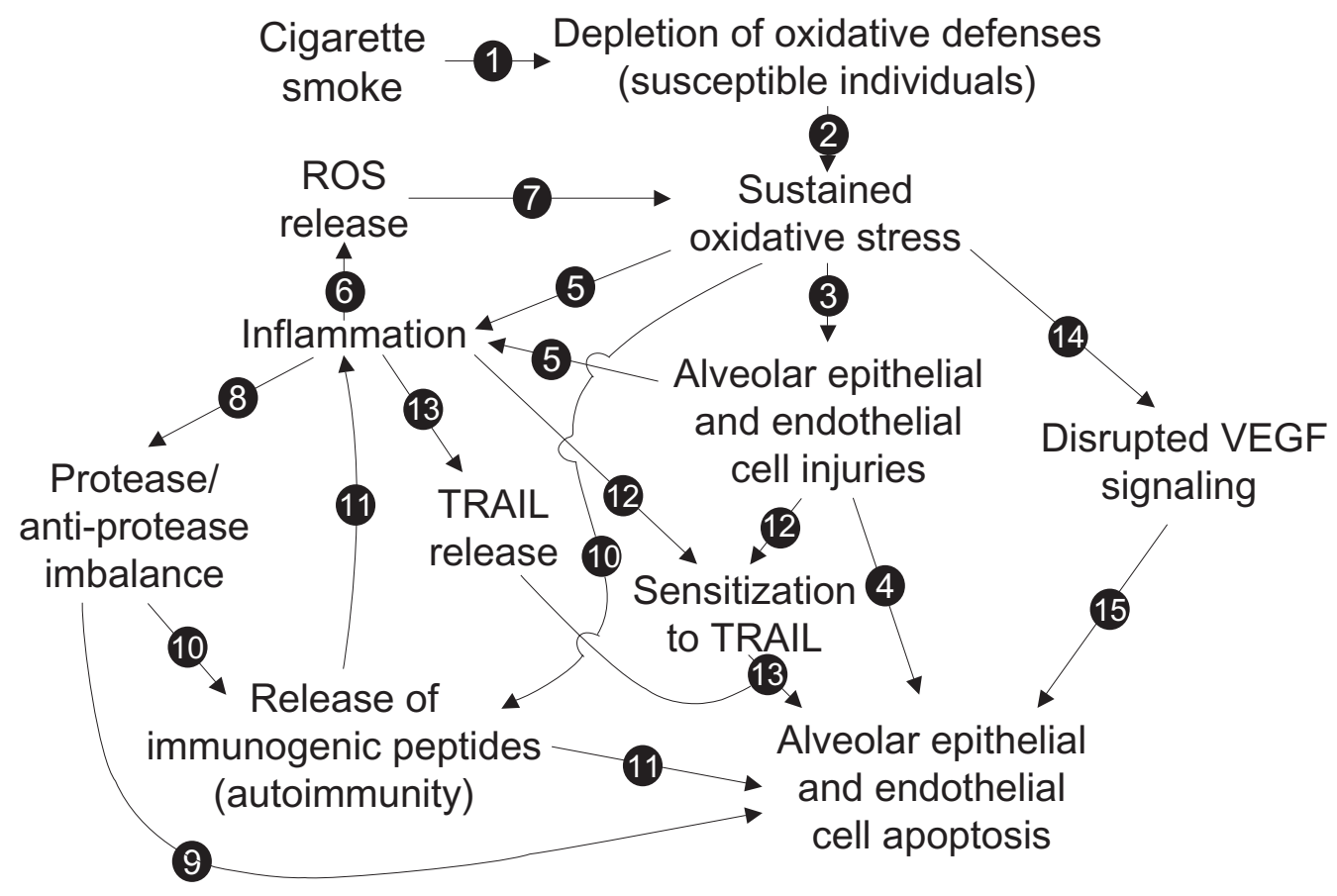

Figure 7 Proposed model of the mechanisms involved in the increased alveolar apoptosis observed in emphysema (see text for details). 
(efferocytosis), ${ }^{96}$ even if very interesting and promising ways of research, were not included in the model.

\section{Global model to explain increased apoptosis in emphysema}

As we know, 90\% of emphysema cases are developed following cigarette smoke exposure. We also know that, among all its toxic power, cigarette smoke contains powerful oxidants. In some individuals with weaker oxidative defenses (genetic feature), chronic cigarette smoke exposure will lead to oxidative defense depletion (see Arrow [1] in Figure 7) and the establishment of a sustained oxidative stress [2] leading to lethal injuries to alveolar cells [3] and an increase in alveolar cell apoptosis [4]. Oxidative stress can also be responsible for the initiation of an inflammatory process, either from direct immune cell activation or through the release of inflammatory mediators by injured alveolar cells [5]. In the present model, the following steps are very important to establish the chronic state of the disease. Activated inflammatory cells, mainly neutrophils and macrophages, are well known to be powerful reactive oxygen species (ROS) producers [6]. ROS released from inflammatory cells may then be involved in the establishment of a cigarette smoke-independent lung oxidative stress [7], as oxidative stress remains in the lung of emphysematous subjects after smoking cessation. Activated neutrophils and macrophages can also release great amount of proteases that then lead to lung protease/anti-protease imbalance [8] and induce alveolar epithelial and endothelial apoptosis [9]. Protease hyperactivity and oxidative stress could also be responsible for the release of immunogenic peptides [10] and lead to the development of antigen-driven immune response (antigen-specific activation of B cells and CD4+ and CD8+ T cells) and then promote alveolar cell apoptosis [11]. Inflammatory mediators, like TNF, and oxidative stress (cell injuries) can also modulate elements involved in alveolar cell sensitivity to TRAIL-mediated apoptosis (TRAIL receptors, p53, and Bax levels) [12] and switch alveolar cells from a TRAIL-mediated apoptosis resistant state to a sensitive state and lead to increased alveolar cell apoptosis [13]. Oxidative stress may also be responsible for the disruption of VEGF signaling [14], leading to alveolar endothelial cell apoptosis, and, through a lack of physical support, promoting alveolar epithelial cell apoptosis [15].

Based on this model of hypothesis, tools such as DNA and protein microarrays and softwares for cellular pathway interactions analysis will help to see in a more global way the pathways involved in the disease development while new primary cell isolation and culture will give better cellular models. All this will increase the comprehension of the different mechanisms involved in emphysema pathogenesis and ultimately lead the elaboration of treatments that will stop the development or the progression of the disease.

\section{Disclosure}

The authors report no conflicts of interest in this work. MCM is the recipient of a studentship from the Fonds de Recherche en Santé du Québec.

\section{References}

1. Murray CJ, Lopez AD. Alternative projections of mortality and disability by cause 1990-2020: Global Burden of Disease Study. Lancet. 1997;349:1498-1504.

2. Hogg JC. Pathophysiology of airflow limitation in chronic obstructive pulmonary disease. Lancet. 2004;364:709-721.

3. Mulgrew AT, Taggart CC, McElvaney NG. Alpha-1-antitrypsin deficiency: current concepts. Lung. 2007;185:191-201.

4. Quint JK, Wedzicha JA. The neutrophil in chronic obstructive pulmonary disease. J Allergy Clin Immunol. 2007;119:1065-1071.

5. Barnes PJ. Alveolar macrophages in chronic obstructive pulmonary disease (COPD). Cell Mol Biol (Noisy-le-grand). 2004;50: OL627-OL637.

6. Cosio MG, Majo J, Cosio MG. Inflammation of the airways and lung parenchyma in COPD: role of T cells. Chest. 2002;121:160S-165S.

7. Strasser A, O'Connor L, Dixit VM. Apoptosis signaling. Annu Rev Biochem. 2000;69:217-245.

8. Roos WP, Kaina B. DNA damage-induced cell death by apoptosis. Trends Mol Med. 2006;12:440-450.

9. Elmore S. Apoptosis: a review of programmed cell death. Toxicol Pathol. 2007;35:495-516.

10. Imai K, Mercer BA, Schulman LL, et al. Correlation of lung surface area to apoptosis and proliferation in human emphysema. Eur Respir J. 2005;25:250-258.

11. Yokohori N, Aoshiba K, Nagai A. Increased levels of cell death and proliferation in alveolar wall cells in patients with pulmonary emphysema. Chest. 2004;125:626-632.

12. Yang JJ, Kettritz R, Falk RJ, et al. Apoptosis of endothelial cells induced by the neutrophil serine proteases proteinase 3 and elastase. Am J Pathol. 1996;149:1617-1626.

13. Ginzberg HH, Shannon PT, Suzuki T, et al. Leukocyte elastase induces epithelial apoptosis: role of mitochondial permeability changes and Akt. Am J Physiol Gastrointest Liver Physiol. 2004;287:G286-G298.

14. Suzuki T, Moraes TJ, Vachon E, et al. Proteinase-activated receptor-1 mediates elastase-induced apoptosis of human lung epithelial cells. Am J Respir Cell Mol Biol. 2005;33:231-247.

15. Petrache I, Fijalkowska I, Medler TR, et al. alpha-1 antitrypsin inhibits caspase-3 activity, preventing lung endothelial cell apoptosis. Am J Pathol. 2006;169:1155-1166.

16. Aldonyte R, Hutchinson ET, Jin B, et al. Endothelial alpha-1-antitrypsin attenuates cigarette smoke induced apoptosis in vitro. COPD. 2008;5:153-162.

17. Chirco R, Liu XW, Jung KK, et al. Novel functions of TIMPs in cell signaling. Cancer Metastasis Rev. 2006;25:99-113.

18. Eriksson S. Pulmonary emphysema and alpha1-antitrypsin deficiency. Acta Med Scand. 1964;175:197-205.

19. Gross P, Pfitzer EA, Tolker E, et al. Experimental emphysema: its production with papain in normal and silicotic rats. Arch Environ Health. 1965;11:50-58.

20. Yoshioka A, Betsuyaku T, Nishimura M, et al. Excessive neutrophil elastase in bronchoalveolar lavage fluid in subclinical emphysema. Am J Respir Crit Care Med. 1995;152:2127-2132. 
21. Takeyabu K, Betsuyaku T, Nishimura M, et al. Cysteine proteinases and cystatin $\mathrm{C}$ in bronchoalveolar lavage fluid from subjects with subclinical emphysema. Eur Respir J. 1998;12:1033-1039.

22. Segura-Valdez L, Pardo A, Gaxiola M, et al. Upregulation of gelatinases $\mathrm{A}$ and $\mathrm{B}$, collagenases 1 and 2 , and increased parenchymal cell death in COPD. Chest. 2000;117:684-694.

23. Imai K, Dalal SS, Chen ES, et al. Human collagenase (matrix metalloproteinase-1) expression in the lungs of patients with emphysema. Am J Respir Crit Care Med. 2001;163:786-791.

24. Ohnishi K, Takagi M, Kurokawa Y, et al. Matrix metalloproteinasemediated extracellular matrix protein degradation in human pulmonary emphysema. Lab Invest. 1998;78:1077-1087.

25. Babusyte A, Stravinskaite K, Jeroch J, et al. Patterns of airway inflammation and MMP-12 expression in smokers and ex-smokers with COPD. Respir Res. 2007;8:81.

26. Stone PJ, Lucey EC, Calore JD, et al. Defenses of the hamster lung against human neutrophil and porcine pancreatic elastase. Respiration. 1988;54:1-15.

27. Lucey EC, Keane J, Kuang PP, et al. Severity of elastase-induced emphysema is decreased in tumor necrosis factor-alpha and interleukin1 beta receptor-deficient mice. Lab Invest. 2002;82:79-85.

28. Zheng T, Kang MJ, Crothers K, et al. Role of cathepsin S-dependent epithelial cell apoptosis in IFN-gamma-induced alveolar remodeling and pulmonary emphysema. J Immunol. 2005;174:8106-8115.

29. Ferrara N, Gerber HP, LeCouter J. The biology of VEGF and its receptors. Nat Med. 2003;9:669-676.

30. Gerber HP, Dixit V, Ferrara N. Vascular endothelial growth factor induces expression of the antiapoptotic proteins Bcl-2 and A1 in vascular endothelial cells. J Biol Chem. 1998;273:13313-13316.

31. Gupta K, Kshirsagar S, Li W, et al. VEGF prevents apoptosis of human microvascular endothelial cells via opposing effects on MAPK/ERK and SAPK/JNK signaling. Exp Cell Res. 1999;247:495-504.

32. Gerber HP, McMurtrey A, Kowalski J, et al. Vascular endothelial growth factor regulates endothelial cell survival through the phosphatidylinositol 3'-kinase/Akt signal transduction pathway. Requirement for Flk-1/KDR activation. J Biol Chem. 1998;273:30336-30343.

33. Cardone MH, Roy N, Stennicke HR, et al. Regulation of cell death protease caspase-9 by phosphorylation. Science. 1998;282:1318-1321.

34. del Peso L, Gonzalez-Garcia M, Page C, et al. Interleukin-3-induced phosphorylation of BAD through the protein kinase Akt. Science. 1997;278:687-689.

35. Tran J, Rak J, Sheehan C, et al. Marked induction of the IAP family antiapoptotic proteins survivin and XIAP by VEGF in vascular endothelial cells. Biochem Biophys Res Commun. 1999;264:781-788.

36. Kanazawa H. Role of vascular endothelial growth factor in the pathogenesis of chronic obstructive pulmonary disease. Med Sci Monit. 2007;13:RA189-195.

37. Voelkel NF, Vandivier RW, Tuder RM. Vascular endothelial growth factor in the lung. Am J Physiol Lung Cell Mol Physiol. 2006;290: L209-L221.

38. Marwick JA, Stevenson CS, Giddings J, et al. Cigarette smoke disrupts VEGF165-VEGFR-2 receptor signaling complex in rat lungs and patients with COPD: morphological impact of VEGFR-2 inhibition. Am J Physiol Lung Cell Mol Physiol. 2006;290:L897-908.

39. Kasahara Y, Tuder RM, Cool CD, et al. Endothelial cell death and decreased expression of vascular endothelial growth factor and vascular endothelial growth factor receptor 2 in emphysema. Am J Respir Crit Care Med. 2001;163:737-744.

40. Kasahara Y, Tuder RM, Taraseviciene-Stewart L, et al. Inhibition of VEGF receptors causes lung cell apoptosis and emphysema. J Clin Invest. 2000;106:1311-1319.

41. Tuder RM, Zhen L, Cho CY, et al. Oxidative stress and apoptosis interact and cause emphysema due to vascular endothelial growth factor receptor blockade. Am J Respir Cell Mol Biol. 2003;29:88-97.

42. Demura Y, Taraseviciene-Stewart L, Scerbavicius R, et al. N-acetylcysteine treatment protects against VEGF-receptor blockade-related emphysema. COPD. 2004;1:25-32.
43. Committee ahS. Mechanisms and limits of induced postnatal lung growth. Am J Respir Crit Care Med. 2004;170:319-343.

44. Acarregui MJ, Penisten ST, Goss KL, et al. Vascular endothelial growth factor gene expression in human fetal lung in vitro. Am J Respir Cell Mol Biol. 1999;20:14-23.

45. Shifren JL, Doldi N, Ferrara N, et al. In the human fetus, vascular endothelial growth factor is expressed in epithelial cells and myocytes, but not vascular endothelium: implications for mode of action. $J$ Clin Endocrinol Metab. 1994;79:316-322.

46. Ng YS, Rohan R, Sunday ME, et al. Differential expression of VEGF isoforms in mouse during development and in the adult. Dev Dyn. 2001;220:112-121.

47. Ryter SW, Kim HP, Hoetzel A, et al. Mechanisms of cell death in oxidative stress. Antioxid Redox Signal. 2007;9:49-89.

48. Jing Y, Dai J, Chalmers-Redman RM, et al. Arsenic trioxide selectively induces acute promyelocytic leukemia cell apoptosis via a hydrogen peroxide-dependent pathway. Blood. 1999;94:2102-2111.

49. Serrano J, Palmeira CM, Kuehl DW, et al. Cardioselective and cumulative oxidation of mitochondrial DNA following subchronic doxorubicin administration. Biochim Biophys Acta. 1999;1411:201-205.

50. Hug H, Strand S, Grambihler A, et al. Reactive oxygen intermediates are involved in the induction of CD95 ligand mRNA expression by cytostatic drugs in hepatoma cells. J Biol Chem. 1997;272:28191-28193.

51. Suzuki S, Higuchi M, Proske RJ, et al. Implication of mitochondria-derived reactive oxygen species, cytochrome $\mathrm{C}$ and caspase- 3 in N-(4-hydroxyphenyl)retinamide-induced apoptosis in cervical carcinoma cells. Oncogene. 1999;18:6380-6387.

52. Carvalho H, Evelson P, Sigaud S, et al. Mitogen-activated protein kinases modulate $\mathrm{H}(2) \mathrm{O}(2)$-induced apoptosis in primary rat alveolar epithelial cells. J Cell Biochem. 2004;92:502-513.

53. Rahman I, Biswas SK, Kode A. Oxidant and antioxidant balance in the airways and airway diseases. Eur J Pharmacol. 2006;533:222-239.

54. Pryor WA. Cigarette smoke radicals and the role of free radicals in chemical carcinogenicity. Environ Health Perspect. 1997;105 (Suppl 4):875-882.

55. Willemse BW, Postma DS, Timens W, et al. The impact of smoking cessation on respiratory symptoms, lung function, airway hyperresponsiveness and inflammation. Eur Respir J. 2004;23:464-476.

56. Russell RE, Culpitt SV, DeMatos C, et al. Release and activity of matrix metalloproteinase- 9 and tissue inhibitor of metalloproteinase- 1 by alveolar macrophages from patients with chronic obstructive pulmonary disease. Am J Respir Cell Mol Biol. 2002;26:602-609.

57. Russell RE, Thorley A, Culpitt SV, et al. Alveolar macrophage-mediated elastolysis: roles of matrix metalloproteinases, cysteine, and serine proteases. Am J Physiol Lung Cell Mol Physiol. 2002;283:L867-73.

58. Lacoste JY, Bousquet J, Chanez P, et al. Eosinophilic and neutrophilic inflammation in asthma, chronic bronchitis, and chronic obstructive pulmonary disease. J Allergy Clin Immunol. 1993;92:537-548.

59. Keatings VM, Barnes PJ. Granulocyte activation markers in induced sputum: comparison between chronic obstructive pulmonary disease, asthma, and normal subjects. Am J Respir Crit Care Med. 1997;155:449-453.

60. Gwinn MR, Vallyathan V. Respiratory burst: role in signal transduction in alveolar macrophages. J Toxicol Environ Health B Crit Rev. 2006;9:27-39.

61. Dahlgren C, Karlsson A. Respiratory burst in human neutrophils. J Immunol Methods. 1999;232:3-14.

62. Rahman I, van Schadewijk AA, Crowther AJ, et al. 4-Hydroxy-2nonenal, a specific lipid peroxidation product, is elevated in lungs of patients with chronic obstructive pulmonary disease. Am J Respir Crit Care Med. 2002;166:490-495.

63. Malhotra D, Thimmulappa R, Navas-Acien A, et al. Decline in NRF2 Regulated Antioxidants in COPD Lungs due to Loss of its Positive Regulator DJ-1. Am J Respir Crit Care Med. 2008.

64. Falschlehner C, Emmerich CH, Gerlach B, et al. TRAIL signalling: decisions between life and death. Int J Biochem Cell Biol. 2007;39:1462-1475. 
65. Bonavida B, Ng CP, Jazirehi A, Schiller G, Mizutani Y. Selectivity of TRAIL-mediated apoptosis of cancer cells and synergy with drugs: the trail to non-toxic cancer therapeutics. Int J Oncol. 1999;15:793-802.

66. Zhang L, Fang B. Mechanisms of resistance to TRAIL-induced apoptosis in cancer. Cancer Gene Ther. 2005;12:228-237.

67. Hu H, Jiang C, Schuster T, et al. Inorganic selenium sensitizes prostate cancer cells to TRAIL-induced apoptosis through superoxide/p53/Baxmediated activation of mitochondrial pathway. Mol Cancer Ther. 2006;5:1873-1882.

68. Fan QL, Zou WY, Song LH, et al. Synergistic antitumor activity of TRAIL combined with chemotherapeutic agents in A549 cell lines in vitro and in vivo. Cancer Chemother Pharmacol. 2005;55:189-196.

69. Frese S, Brunner T, Gugger M, et al. Enhancement of Apo2L/TRAIL (tumor necrosis factor-related apoptosis-inducing ligand)-induced apoptosis in non-small cell lung cancer cell lines by chemotherapeutic agents without correlation to the expression level of cellular protease caspase-8 inhibitory protein. J Thorac Cardiovasc Surg. 2002;123:168-174.

70. Uberti D, Ferrari-Toninelli G, Bonini SA, et al. Blockade of the tumor necrosis factor-related apoptosis inducing ligand death receptor DR5 prevents beta-amyloid neurotoxicity. Neuropsychopharmacology. 2007;32:872-880.

71. Robertson NM, Zangrilli JG, Steplewski A, et al. Differential expression of TRAIL and TRAIL receptors in allergic asthmatics following segmental antigen challenge: evidence for a role of TRAIL in eosinophil survival. J Immunol. 2002;169:5986-5996.

72. Robertson NM, Rosemiller M, Lindemeyer RG, et al. TRAIL in the airways. Vitam Horm. 2004;67:149-167.

73. Mirandola P, Ponti C, Gobbi G, et al. Activated human NK and CD8+ T cells express both TNF-related apoptosis-inducing ligand (TRAIL) and TRAIL receptors but are resistant to TRAIL-mediated cytotoxicity. Blood. 2004;104:2418-2424.

74. Morissette MC, Vachon-Beaudoin G, Parent J, et al. Increased p53 level, Bax/Bcl-x(L) ratio, and TRAIL receptor expression in human emphysema. Am J Respir Crit Care Med. 2008;178:240-247.

75. Andersen MH, Schrama D, Thor Straten P, et al. Cytotoxic T cells. J Invest Dermatol. 2006;126:32-41.

76. Farag SS, Caligiuri MA. Human natural killer cell development and biology. Blood Rev. 2006;20:123-137.

77. Atassi MZ, Casali P. Molecular mechanisms of autoimmunity. Autoimmunity. 2008;41:123-132.

78. Gaipl US, Kuhn A, Sheriff A, et al. Clearance of apoptotic cells in human SLE. Curr Dir Autoimmun. 2006;9:173-187.

79. Scofield RH. Autoantibodies as predictors of disease. Lancet. 2004;363:1544-1546.

80. Gao H, Neff T, Ward PA. Regulation of lung inflammation in the model of IgG immune-complex injury. Annu Rev Pathol. 2006;1:215-242.

81. Smyth MJ, Cretney E, Kelly JM, et al. Activation of NK cell cytotoxicity. Mol Immunol. 2005;42:501-510.

82. Elson CJ, Barker RN. Helper T cells in antibody-mediated, organspecific autoimmunity. Curr Opin Immunol. 2000;12:664-669.

83. Walter U, Santamaria P. CD8+ T cells in autoimmunity. Curr Opin Immunol. 2005;17:624-631.

84. Feghali-Bostwick CA, Gadgil AS, Otterbein LE, et al. Autoantibodies in patients with chronic obstructive pulmonary disease. Am J Respir Crit Care Med. 2008;177:156-163.
85. Taraseviciene-Stewart L, Scerbavicius R, Choe KH, et al. An animal model of autoimmune emphysema. Am J Respir Crit Care Med. 2005; 171:734-742.

86. Lee SH, Goswami S, Grudo A, et al. Antielastin autoimmunity in tobacco smoking-induced emphysema. Nat Med. 2007; 13:567-569.

87. Sullivan AK, Simonian PL, Falta MT, et al. Oligoclonal CD4+ T cells in the lungs of patients with severe emphysema. Am J Respir Crit Care Med. 2005; 172:590-596.

88. Sullivan AK, Simonian PL, Falta MT, et al. Activated oligoclonal CD4+ T cells in the lungs of patients with severe emphysema. Proc Am Thorac Soc. 2006;3:486.

89. Korn S, Wiewrodt R, Walz YC, et al. Characterization of the interstitial lung and peripheral blood $\mathrm{T}$ cell receptor repertoire in cigarette smokers. Am J Respir Cell Mol Biol. 2005;32:142-148.

90. Chrysofakis G, Tzanakis N, Kyriakoy D, et al. Perforin expression and cytotoxic activity of sputum CD8+ lymphocytes in patients with COPD. Chest. 2004;125:71-76.

91. Hodge S, Hodge G, Nairn J, et al. Increased airway granzyme b and perforin in current and ex-smoking COPD subjects. COPD. 2006;3:179-187.

92. Morissette MC, Parent J, Milot J. Perforin, granzyme B, and FasL expression by peripheral blood $\mathrm{T}$ lymphocytes in emphysema. Respir Res. 2007;8:62.

93. Liu CY, Lin HC, Yu CT, et al. The concentration-dependent chemokine release and pro-apoptotic effects of neutrophil-derived alpha-defensin-1 on human bronchial and alveolar epithelial cells. Life Sci. 2007;80:749-758.

94. Aarbiou J, Tjabringa GS, Verhoosel RM, et al. Mechanisms of cell death induced by the neutrophil antimicrobial peptides alpha-defensins and LL-37. Inflamm Res. 2006;55:119-127.

95. Taraseviciene-Stewart L, Voelkel NF. Molecular pathogenesis of emphysema. J Clin Invest. 2008;118:394-402.

96. Vandivier RW, Henson PM, Douglas IS. Burying the dead: the impact of failed apoptotic cell removal (efferocytosis) on chronic inflammatory lung disease. Chest. 2006;129:1673-1682.

97. Calabrese F, Giacometti C, Beghe B, et al. Marked alveolar apoptosis/proliferation imbalance in end-stage emphysema. Respir Res. 2005;6:14.

98. Aoshiba K, Yokohori N, Nagai A. Alveolar wall apoptosis causes lung destruction and emphysematous changes. Am J Respir Cell Mol Biol. 2003;28:555-562.

99. Bartalesi B, Cavarra E, Fineschi S, et al. Different lung responses to cigarette smoke in two strains of mice sensitive to oxidants. Eur Respir J. 2005;25:15-22.

100. Kuo WH, Chen JH, Lin HH, et al. Induction of apoptosis in the lung tissue from rats exposed to cigarette smoke involves p38/JNK MAPK pathway. Chem Biol Interact. 2005;155:31-42.

101. Petrache I, Natarajan V, Zhen L, et al. Ceramide upregulation causes pulmonary cell apoptosis and emphysema-like disease in mice. Nat Med. 2005;11:491-498.

102. Brass DM, Hollingsworth JW, Cinque M, et al. Chronic LPS Inhalation Causes Emphysema-like Changes in Mouse Lung that is Associated with Apoptosis. Am J Respir Cell Mol Biol. 2008. 
